\title{
TANGGUNG GUGAT IZIN MENDIRIKAN BANGUNAN MENURUT PERATURAN DAERAH KABUPATEN GRESIK
}

\author{
Oleh : \\ Abdul Basid*, Handrik Setiawan** \\ "Fakultas Hukum, Universitas Gresik \\ Email : abdulbasid654@gmail.com \\ ${ }^{* *}$ Fakultas Hukum, Universitas Gresik
}

\begin{abstract}
ABSTRAK
Penelitian ini mengangkat masalah tanggung jawab gugat bagi bangunan yang tidak memiliki izin mendirikan bangunan menimbulkan gangguan lingkungan dan pelaksanaansanksi hukum administrasi yang harus diterapkan pada bangunan yang tidak memiliki izin mendirikan bangunan. Penelitian ini bersifat deskriptif analisis yaitu penelitian yang memberikan data tentang suatu keadaan atau gejala-gejala sosial yang berkembang di tengah- tengah masyarakat sehingga dengan adanya penelitian ini diharapkan dapat memperoleh gambaran yang menyeluruh, lengkap dan sistematis tentang objek yang akan diteliti.Padapenelitian ini mengkajisebuahsubjektentang akibat gangguan lingkungan dan sanksi hukum administrasi pada Peraturan Daerah Kabupaten Gresik Nomor 06 Tahun 2017 Tentang Izin Mendirikan Bangunan.Kesimpulan Penelitian ini Banyak faktor yang menghambat implementasi Perda. Namun yang paling mencolok adalah kesadaran masyarakat yang rendah terhadap IMB dalam mendirikan bangunan. Kesadaran bahwa IMB berguna untukmewujudkan kota yang tertib, rapi, indah, dan nyaman masih kurang. Kesadaran masyarakat ini disinyalir karena sosialisasi program dan sistem sanksi yang lemah.
\end{abstract}

Kata Kunci : Izin Mendirikan Bangunan, Sanksi Administratif, Tanggung Jawablingkungan

\section{PENDAHULUAN (font 12pt, bold, capital)}

Izin Mendirikan Bangunan adalah produk hukum yang berisi persetujuan atau perizinan yang dikeluarkan oleh Kepala Daerah Setempat (Pemerintah kabupaten / kota) dan wajib dimiliki / diurus pemilik bangunan yang ingin membangun,merobohkan,menambah

/mengurangi luas, ataupun merenovasi suatu bangunan.

Izin Mendirikan Bangunan diatur dalam Undang-Undang nomor

28 Tahun 2002 tentang Bangunan Gedung, dimana Undang-undang tersebut menyatakan bahwa untuk mendirikan bangunan gedung di Indonesia diwajibkan untuk memiliki Izin Mendirikan Bangunan. Selain dalam UU nomor 28 Tahun 2002,

IMB diatur dalam Undang-undang nomor 26 tahun 2007 tentang Penataan Ruang dan PP nomor 36 tahun 2005 tentang Peraturan Pelaksanaan Undangundang nomor

28 tahun 2002 tentang Bangunan Gedung.

Menurut Peraturan DaerahKabupaten Gresik Nomor 6 Tahun 2017, Peraturan Daerah ini mengatur tentang penyelenggaraan Izin Mendirikan Bangunan di Kabupaten Gresik, yang mengatur ketentuan- ketentuan mengenai persyaratan administratif dan persyaratan tekni sesuai fungsi dan klasifikasi bangunan gedung Serta didalam Peraturan Daerah Kabupaten Gresik Nomor 6 Tahun 2017, mengatur pulapenerapkan sanksi administrasi kepada setiap orang atau badan usaha yang berbadan hukum atau tidak berbadan hukum yang melanggar Pasal 8 dan Pasal 40.Sanksi administratif sebagaimana dimaksud pada ayat (1) berupa :

1. Peringatan tertulis;

2. pembatasan kegiatan pembangunan;

3. penghentian sementara atautetap pada pelaksanaanpembangunan;

4. penghentian sementara atau tetap pemanfaatanbangunangedung;

5. pembekuan;

6. pencabutan IMB; dan

7. pembongkaran.

Selain itu menurut Peraturan Daerah Kabupaten Gresik Nomor 6 Tahun 2017, menerapkan beberapa peraturan tentang Izin Mendirikan Bangunan antara lain 
Pengaturan fungsi bangunan gedung dalam peraturan daerah ini dimaksudkan agar bangunan gedung maupun prasarana dan sarana bangunan gedung yang didirikan sejak awal telah ditetapkan fungsinyasehingga masyarakat yang akanmendirikan dapat memenuhi persyaratan administratif maupun teknis. Fungsi dimaksud harus sesuai dengan Rencana Tata Ruang Wilayah dan/atau Rencana Detil TataRuang Kabupaten Gresik.

Pengaturan persyaratan administratif dalam Peraturan Daerah ini dimaksudkan agar masyarakat mengetahui lebih rinci persyaratan administratif yang diperlukan untuk mendirikan banguhukum bahwa bangunan gedung maupun prasarana dan sarana gedung, baikdari kejelasan status tanahnya, kejelasan status kepemilikan bangunan gedung maupun kepastian bangunan gedung telah memperoleh persetujuan dari pemerintah darah dalam bentuk Izin Mendirikan Bangunan.

Melihat dari beberbagai penjelasan diatas maka saya dapati sebuah permasalahan yang kompleks yang ditemukan di lapangan antaralain, kesadaran dari pihak pemohon IMB ketika terjadi kesulitan maka jalan pintas yang diambil, mulai dari pemberiah hadiah, nominal uang, dankoneksi.

Dari situ munculah kerugian yang akan diterima oleh sekitar tempat yang akan dibangun tanpa adanya IMB, mulai dari factor bahaya erosi tanah, factor bahaya kebakaran, dan lain2. Maka perlu adanya kesadaran dari pihak terkait baik pemohon IMB dan pemberi IMB, karena dapat merugikanapabila tidak ada kesadaran dari pihak masing- masing

Sedangkan jika melihat daridata Badan Pusat Statistik $^{1}$, Kabupaten Gresik memiliki luas 1.191,25 km2 terdiri dari 993,83 km2luas daratan ditambah sekitar 197,42 km2 luas pulau Bawean. Sedangkan luas wilayah perairan adalah $5.773 .80 \mathrm{~km} 2$ dengan panjang pantai $\pm 140 \mathrm{~km}$ yang sangat potensial untuk perikanan laut. Secara geografis, wilayah Kabupaten Gresik terletak pada posisi antara 7o - 8o LSdan 112o 133o BT. Sebagian besar wilayahnya merupakan dataranrendah dengan ketinggian antara 2 -

12 meter diatas permukaan laut kecuali sebagian kecil di bagian utara (Kecamatan Panceng) mempunyai ketinggian sampai 25 meter diatas permukaan laut.

Karena kondisi tersebut maka perlu adanya peranan dari DinasSatuan Polisi Pamong Praja yang merupakan sebagai ujung tombak di daerah untuk melaksanakan Peraturan Daerah Kabupten Gresik Nomor 6 Tahun 2017 tentang Izin Mendirikan Bangunan yang berkerja sama dengan Dinas DPMPTSP. Untuk memperbaiki pola strukturruang agar menciptakan ruang hijau,
Ruang adalah wujud fisik wilayah dalam dimensi geografis dan geometris yang merupakan wadah bagi manusia dalam melaksanakan kegiatan kehidupannya dalam suatu kualitas kehidupan yang layak. ${ }^{2}$ Tata ruang adalah wujud struktur ruang dan pola ruang. Struktur ruang adalah susunan pusatpusatpermukiman dan sistem jaringan prasarana dan sarana yang berfungsi sebagai pendukung kegiatan sosial ekonomi masyarakat yang secara hierarkis memiliki hubungan fungsional.

Dinas satuan Polisi Pamong Praja sering melakukan pengecekan beberapa perusaan baik perusahaan besar maupun kecil. Banyak dari beberapa perusahaan mengambil jalan pinta suntuk untuk menghindari pajak dengan mengakali izin mendidikan bangunan izin mendirikan bangunan, contoh sebagai berikut : Dinas Satuan Polisi Pamong Praja (Satpol PP). Kabupaten Gresik menyegel perusahan jasa angkutam PT Dwi Raksa, Desa Ambeng-Ambeng, di jalan Ambeng-Ambeng kecamatan Duduksampean. Gresik. Penyegelan dilakukan karena perusahaan tersebut belum memiliki Ijin Mendirikan Bangunan (IMB). Eksekusi serta penyegelan memberhentikan operasi sementara berdasar Perda nomor 6 tahun 2017. Penyegelan sedikit alot, hal itu disebabkan oleh kendala teknis masih mengkoordinasikan berbagai pihak yang terkait. Seperti halnya Dinas Penanaman Modal dan PTSP, Dinas Perhubungan, Dinas PekerjaanUmum dan Tata Ruang, Camat bahkan Komisi III DPRD Gresik. Semua berkoordinasi di kantor Kecamatan Duduksampean Gresik, sebelum melakukan penyegelan. Di depan kepala bagian operasional PT Dwi Raksa, Kepala Dinas Satpol PP Achmad Nurudin menyampaikan penyegelan disebabkan perusahaan kurang kooperatif. Setelah sekian kali di beri surat oleh Dinas Penanaman Modal dan PTSP untuk segera mengurus IMB, namun tidak dilakukannya. Bahkan sudahdipanggil ke Komisi III DPRD Gresik, sebagai penegak Perda, sehingga penyegelan pun dilakukan mengembalikan peranan penataan ruang di Kabupaten Gresik.

Penataan ruang adalah suatu sistem proses perencanaan tata ruang, pemanfaatan tata ruang dan pengendalian pemanfaatan ruangHal tersebut merupakan ruang lingkup penataan ruang sebagai objek HukumAdministrasi Negara.

Padahal, sebelumnya petugas juga berulang kali mengingatkan untuk mengajukan izin, namun tidak direspon pihak pengelola, keenam minimarket yang disegel itu terdiri atas tiga Alfamart dan tiga Indomaret. Penyegelan dilakukan usai beberapa kali melayangkan peringatan mengurus izin di Dinas Penanaman Modal Pelayanan Terpadu Satu Pintu (DPM-PTSP).

Jadi, hukum penataan ruang menurut Undang-Undang Nomor 26 Tahun 2007 yaitu 
hukum yang berwujud struktur ruang ialahsusunan pusat-pusat pemukiman dan sistem jaringan prasarana dan sarana yang berfungsi sebagai pendukung kegiatan ekonomi masyarakat yang secara hierarkis memiliki hubungan fungsional dan pola ruang ialah distribusi peruntukan ruang dalam suatu wilayah yang meliputiperuntukan ruang untuk fungsi lindung dan peruntukan ruang untuk fungsi budi daya

\section{Metode Penelitian}

Penelitian ini menggunakan metode hukum normatif (normatif legal research) metode penelitian hukum normatif atau metode hukum kepustakaan adalah metode atau cara yang di pergunakaan di dalam penelitian hukum yang di lakukan dengan cara meneliti bahan pustaka yang ada ${ }^{4}$.

Yang menemukan aturan hukum, prinsipprinisp hukum, maupun doktrin hukum guna menjawab isu hukum yang dihadapi. Pada penelitian ini mengkaji sebuah sebujek tentang akibat gangguan lingkungan dan sanksi hukum administrasi padaPeraturan DaerahKabupaten Gresik Nomor 06 Tahun 2017 Tentang Izin Mendirikan Bangunan.

\section{Metode Pendekatan}

\section{Pendekatan Perundang -undangan}

Jenis penelitian ini bertujuan untuk menggungkap kenyataan sampai sejauh mana perundang- undangan tertentu serasi secara horizontal, yaitu mempunyai keserasian antara perundang- undangan yang sederajat mengenai bidang yang sama

Didalam penelitian mengenai taraf sinkronisasi secara horizontal ini, mula-mula harus terlebih dahulu dipilih bidang yang akan diteliti ${ }^{5}$. Setelah bidang tersebut ditentukan, misalnya bidang pemerintahan daerah, maka dicarilah peraturan perundang-undangan yang sederajatyang mengatur segala aspek tentang pemerintahan daerah tersebut. Aspek-aspek tersebut merupakan suatu kerangka untuk menyusun klasifikasi peraturan perundangundangan yang telah diseleksi, untuk kemudian dianalisa.

Dari hasil analisa akan dapat terungkap, sampai sejauh mana taraf sinkronisasi secara horizontal dari berbagai macam peraturan perundang-undamgan yang mengatur bidang pemerintahan daerah ini.

Selain mendapatkan data tentang peraturan perundangan- undangan untuk bidang-bidangtertentu secara menyeluruh dan lengkap, maka penelitian dengan pendekatan ini juga dapat menemukan kelemahan-kelemahan yang ada pada peraturan perundangan-undangan dan yang mengatur bidangbidang tertentu. Dengan demikian peneliti dapat membuat rekomendasi untuk melengkapi kekurangan-kekurangan, menghapus kelebihan- kelebihan yang saling tumpang tindih, memperbaiki penyimpangan - penyimpangan yang ada, dan memberi masukan khususnya pemerintah daerah dan bagi masyarakat yang awam dan seterusnya. Hasil-hasil penelitian ini tidak hanya berguna bagi penegak hukum, akan tetapi juga bagi ilmuwan danpendidikan hukum ${ }^{6}$.

\section{Pendekatan Konsep}

Pendekatankonseptual (conceptua l ap pproach) merupakan jenis pendekatan dalam penelitian hukum yang memberikan sudut pandang analisa penyelesaian permasalahandalam penelitian hukum dilihat dari aspek konsep-konsep hukum yang melatar belakanginya, atau bahkan dapat dilihat dari nilai-nilai yang terkandung dalampenormaan sebuah peraturan kaitannya dengan konsep-konsep yang digunakan

\section{Pendekatan perbandingan}

Pendekatan perbandingan merupakan jenis pendekatan yang peneliti mencoba untuk membandingkan baik dengan negara- negara lain maupun dengan peristiwa-peristiwa yang pernah terjadi dalam satu negara. Untuk itu dalam penelitian ini dikenal dengan 2 Pendekatan,perbandingan (comparati ve approach),yakni suatu pendekatan perbandingan makro (macrocomparatiapproach) serta pendekatan perbandingan mikro(microcompartive approach). ${ }^{7}$

\section{Sumber Hukum}

Penelitian ini membutuhkan 2 (dua) jenis data.Data yang akan dikumpulkan adalah data primer dan data sekunder.

\section{a. Data Primer}

Data primer yaitu data yang diperoleh langsung dari sumber pertama ${ }^{8}$. Dalam penelitian ini data primer merupakan hasil dari wawancara dengan pejabat yang memiliki kewenangan mengenai pelaksanaan harian yaitu Dinas Satuan Polisi Pamong Praja, serta Dinas yang memiliki kewenangan mengeluarkan izin di Kabupaten Gresik Yaitu Dinas Penanaman Modal dan Pelayanan Terpadu Satu Pintu (DPM-PTSP).

b. Data Sekunder

Data sekunder yaitu data yangmencakup dokumendokumen resmi, buku-buku, hasil-hasil penelitian yang berwujud laporan, dan sebagainya ${ }^{9}$. Data sekundermerupakan data telah dibukukan dalam literatur yang dapat diperoleh dengan melakukan studi pustaka dari bahan kepustakaan hukum

\section{A. Tinjauan Perizinan}




\section{Pengertian Izin}

Berdasarkan apa yang dikatakan oleh Spelt dan ten Berge, dalam izin dapat dipahami bahwa suatu pihak tidak dapat melakukan sesuatu kecuali diizinkan. Artinya, kemungkinan untuk seseorang atau suatu pihak melakukan sesuatu tersebut tertutup kecuali diizinkan oleh pemerintah. Dengan demikian, pemerintah mengikatkan perannya dalam kegiatan yang dilakukan oleh orang atau pihak yang bersangkutan. ${ }^{10}$

\section{Tujuan Sistem Perizinan}

Melalui izin, pemerintah terlibat dalam kegiatan warga negara.Dalam hal ini pemerintah mengarahkan warganya melalui instrumen yuridis berupa izin. Kadang kala kebijakan pemerintah untuk terlibat dalam kegiatan masyarakat, bahkan tidak berhenti pada satu tahap, melainkan melalui serangkaian kebijakan. Setelah izin diproses, masih dilakukan pengawasan, pemegang izin diwajibkan menyampaikan laporan secara berkala dan sebagainya.

\section{B. Urgensi Izin}

Mekanisme perizinan dan izin yang diterbitkan untuk pengendalian dan pengawasan administratif bisa dipergunakan sebagai alat untuk mengevaluasi keadaan dan tahapan perkembangan yang ingin dicapai, disamping untuk pengendalian arah perubahan dan mengevaluasi keadaan, potensi, serta kendala yang dibentuk untuk berubah. ${ }^{11}$

Perizinan bisa merupakan instrumen yang dapat dimanfaatkan oleh pemerintah sebagai ujung tombak dalam mengendalikan aktivitas rakyatnya. Makna dari suatu tindakan hukum pemerintah berupa perizinan adalah melarang seseorang atau badan hukum tertentu melakukan suatu kegiatan dan/atau usaha tanpa mendapatkan persetujuan/perkenanterlebih dahulu dari badan atau pejabattata usaha negara yang berwenang

Penggunaan kewenangan yang dilakukan oleh pejabat tata usaha negara tidak hanya untuk mengatur, tetapi juga untuk menetapkan. Dalamhal penetapan yang ditujukan kepada perseorangan,

kewenanganpemerintah harus dilaksanakan berdasarkan pada hukum yang jelas sehingga hal tersebut dapat dipertanggungjawabkan. Salah satu penetapan yang banyak dikeluarkan oleh pemerintah adalahizin.Beberapa urgensi dari izin antaralain $^{12}$

\section{Izin sebagai Landasan Hukum (Legal Base)}

Izin dapat dikatakan sebagai landasan hukum izin menjadi dasar hukum bagi pelaku kegiatan untuk dapat memulai kegiatan tersebut. Hak dan kewajiban pemohon izin berkaitan dengan dilakukannya kegiatan dan lahir setelah ada izin. Tanpa izin, suatu pihak tidak dapat melakukan kegiatan yang dimuat dalam izin itu. Kalau tetap sajadilakukan maka dapat dikatakan bahwa kegiatan itu melanggarhukum. kewajiban pemenuhan persyaratan yang di dalamnya termasuk serangkaian pengujian.

\section{Izin sebagai Instrumen untuk Menjamin Kepastian Hukum}

Di dalam izin pada umumnya dimuat berbagai hal, baik yang bersifat subjektif maupun objektif, misalnya, dapat dilihat dalam izin itu siapa yang diberikan hak untuk dapat melakukan kegiatan yang identitasnya sering kali telah tercantum dengan jelas.

\section{Izin sebagai Instrumen untuk Kepentingan Melindungi}

Izin sebagai sebuah keputusan dapat digunakan untuk menjadiinstrumen perlindungan kepentingan,baik itu kepentingan pemohon, kepentingan pemerintah, maupunkepentingan lain. Kiranya dapat dimengerti izin dapat digunakan untuk melindungi kepentingan pemegang izin karena untuk diizinkan melakukan kegiatantertentu sering kali tidak lepas dari,

\section{Izin sebagai Alat Bukti dalam Hal Ada Klaim}

Sebagai sebuah keputusan yang dikeluarkan oleh pemerintah dan dijadikan sebagai dasar untuk melakukan kegiatan, izin dapat digunakan sebagai alat bukti bahwa yang bersangkutan telah mendapatkan perbolehan dari pemerintah. Artinya, kalau menyangkut suatu kegiatan tertentuakan dapat dilihat siapa yang diizinkan, 
sejak kapan, untuk berapa lama, dilakukan di mana, dan seterusnya

\section{Tinjauan terhadap Izin Mendirikan Bangunan}

\section{Pengertian Izin Mendirikan Bangunan}

Pembangunan ialah suatu usaha atau rangkaian usaha pertumbuhan dan perubahan ke arah yang lebih baik melalui upaya yang dilakukan secara terencana ${ }^{13}$ Pengertian Izin Mendirikan Bangunan (IMB) lebih lanjut terdapat pada bagian penjelasanPasal 8 ayat (1) huruf c dalam Undang-Undang Nomor 28 Tahun 2002 tentang Bangunan Gedung. Pembangunan juga merupakansebuah program yang dilakukan secara berencana dibidang fisik dan spiritual dalam rangka pembangunan manusia Indonesia seutuhnya.Pembangunan yang lebih sederhana yaitu sebagai suatu proses perubahanke arah yang lebih baik melalui upaya yang dilakukan secara terencana Pengertian Izin Mendirikan Bangunan (IMB) lebih lanjut terdapat pada bagian penjelasanPasal 8 ayat (1) huruf c dalam Undang-Undang Nomor 28 Tahun 2002 tentang Bangunan Gedung

Didefinisikan bahwa Izin Mendirikan Bangunan adalah surat bukti dari Pemerintah Daerah bahwa pemilik bangunan gedung dapat mendirikan bangunan sesuai fungsi yang telah ditetapkan dan berdasarkan rencana teknis bangunan gedung yang telah disetujui oleh Pemerintah Daerah.

\section{Subjek Hukum yang dapat Memperoleh Izin}

Dalam Pasal 1 angka 9 Undang- Undang Republik Indonesia Nomor

28 Tahun 2002 tentang Bangunan Gedung didefinisikan pemilik bangunan gedung adalah orang, badan hukum, kelompok orang, atau perkumpulan, yang menurut hukum sah sebagai pemilik bangunan gedung.

Orang atau badan hukum dalam UndangUndang ini meliputi orang perorangan atau badan hukum. Badan hukum privat antara lain adalah perseroan terbatas, yayasan, badan usaha yang lain seperti CV,firma dan bentuk usaha lainnya, sedangkan badan hukum publikantara lain terdiri dari instansi / lembaga pemerintahan, perusahaan milik negara, perusahaan milik daerah, perum, perjan, dan persero dapat pula sebagai pemilik bangunan gedung atau bagian bangunangedung.

\section{Syarat untuk mendapatkanIzin}

Mendirikan Bangunan Berdasarkan

dari hasil wawancaradengan Bapak

Mujiono, sebagaiKepala Seksi

Promosi, PengolahanDatadan Informasi

DinasPenanaman Modal dan

PelayananTerpadu Satu Pintu

(DPMPST)Kabupaten Gresik.

Beliaumengatakan bahwa

seseorang untukmendapatkan izin

mendirikan sebuahbangunan, maka

pemohon izin harusmempunyai:

1. izin penggunaan pemanfaatan tanah/izin pemanfaatan ruang;

2. dokumen perolehan tanah;

3. dokumen lingkungan;

4. rencana tata bangunan.

Syaratnya ialah:

1. pemohon melampirkan permohonan tertulis

2. fotocopy Kartu Tanda Penduduk (KTP) pemohon;

3. fotocopy Pajak Bumi dan Bangunan (PBB);

4. fotocopy bukti kepemilikan tanah;

5. pertimbangan teknis pertanahan bila keadaan tanah bukan pekarangan;

6. rencana tata bangunan, serta syarat lain sesuai peraturan perundangundangan yang berlaku. ${ }^{14}$

Kesimpulan dari pengertian diatas adalah mekanisme dalam pengajuan izin dapat dilakukan sebelum nya agar tidak menanggu proses maupun dampak yang akan ditimbulkan nantinya.

Dengan dipenuhinya persyaratan teknis sesuai fungsi dan klasifikasinya, maka diharapkan kegagalan konstruksi bangunan gedung maupun prasarana dan saranabangunan gedung dapat dihindari, sehingga pengguna bangunan dapathidup lebih tenang dan sehat, rohaniah dan jasmaniah yang akhirnya dapat lebih baik dalam berkeluarga, bekerja, bermasyarakat dan bernegara. Pengaturan bangunan gedung serta prasarana dan saranan bangunan gedung dilandasi oleh azas kemanfaatan, keselamatan, keseimbangan dan keserasianbangunan gedung 
dan lingkungannya bagi masyarakat yang berperikemanusiaan dan berkeadilan. Oleh karena itu masyarakat diupayakan untuk terlibat dan berperan aktif, positif, konstruktif dan bersinergi bukan hanya dalam rangka

pembangunan dan pemanfaatan bangunan gedung untukkepentingan sendiri, tetapi juga dalam meningkatkan pemenuhan persyaratan bangunan gedung dan tertib penyelenggaraan bangunan gedung pada umumnya. Penyelenggaraan bangunan gedung tidak terlepas dari peran penyedia jasa konstruksi baik sebagai perencana, pelaksana, pengawas ataumanagemen konstruksi maupun jasa-jasa pengembangannya, termasukpenyedia jasa pengkaji teknis bangunan gedung, danpelaksanaannya juga berdasarkanPeraturan Perundang-undangan di bidang jasa konstruksi. Penegakan hukum menjadibagian yang penting dalam upaya melindungi kepentingan semua pihakagar memperoleh keadilan dalam hakdan kewajibannya dalam penyelenggaraan bangunan gedung. Penegakan dan penerapan sanksi administratif perlu dimasyarakatkandan diterapkan secara bertahap agar tidak menimbulkan ekses di lapangan dengan tetap mempertimbangkan keadilan dan Ketentuan Perundang- undangan lain Peraturan Daerah Kabupaten Gresik Nomor 6 Tahun 2017 Tentang Izin Mendirikan Bangunan

Bab III Pasal 7 Bagian Kesatu Umum mengenai Persyaratan Permohonan Penerbitan IMB, Persyaratan penerbiatan IMB meliputi, Persyaratan administratif dan persyaratan teknis. Dalam bagian kedua Pasal 9, menjelaskan tentang pengajukan permohonan IMB harus memenuhi seluruh persyaratan administratif dan persyaratan teknis yang diatur dalam Peraturan Daerah ini. Persyaratan administratif meliputi:

1. data pemohon;

2. data tanah; dan

3. dokumen dan surat terkait Serta pada bagian ketiga paragraph I umum Pasal 10,

1. Menjelaskan tentang persyaratan teknis yang meliputi, data umum bangunan gedung; dan dokumen rencana teknis bangunan gedung Bahwa setiap pemilik dan/atau pengguna bangunan gedung yangtidak memenuhi kewajibanpemenuhan fungsi, dan/atau persyaratan, dan/ataupenyelenggaraan bangunan gedung dapat dikenai sanksi administrativedan/atau sanksi pidana sebagaimana dimaksud dalam Peraturan Daerah Kabupaten Gresik Nomor 6 Tahun2017 tentang Izin MendirikanBangunan yaitu : Peringatan tertulis;

2. Pembatasan kegiatan pembangunan;

3. Penghentian sementara atautetap pada pelaksanaan pembangunan;

4. Penghentian sementara atau tetap pemanfaatan bangunan gedung;

5. Pembekuan;

6. Pencabutan IMB; dan

7. pembongkaran.

Berdasarkan permasalahan yang dibahas dalam skripsi ini, pemohon yang tidak memiliki izin mendirikan bangunan jelas melanggar aturan karena sebelumnya telah mendapat sanksi administratif berupa peringatan tertulis dan pembatasan kegiatan pembangunan dari Pemerintah Daerah

\section{Kesimpulan}

Secara umum Peraturan Daerah Gresik Nomor 6 Tahun 2017 tentang Izin Mendirikan Bangunan belumsepenuhnya berjalan baik. Hal ini dapat dilihat dari permasalahan- permasalahan yang masih muncul dalam pelaksanaan Perda tersebut. Dari aspek pelayanan yang diberikan oleh Dinas Penanaman Modal dan Pelayanan Terpadu Satu Atapsebagai tempat permohonan IMBsudah baik apalagi dengan diterapkannya sistem online. Sistem online mempersingkat proses perizinan daripada sebelum diterapkannya sistem online yangtidak memberi kepastian waktu. Hanya saja dari segi sosialisasi dan pengawasan masih kurang maksimal.Masih

banyak ditemukan pembangunan tanpa IMB dan pelanggaran terhadap ketentuan IMB terbilang tinggi,

\section{DAFTAR BUKU BACAAN}

Akib, Muhammad, Charles Jackson dkk. Hukum Penataan Ruang. Bandar lampung: Pusat Kajian Konstitusi dan Peraturan Perundang

Undangan Fakultas Hukum Universitas Lampung. 2013. Amirudin dan Asikin Zaenal, Pengantar Metode 
Penelitian Hukum, Jakarta, PT Raja Grafindo Persada.2012.

Badan Pusat Statistik Kabupaten Gresik, Seksi Neraca Wilayah Dan Analisa Statistik Daerah Kabupaten Gresik,2019.

C.F.G Hartono, Sunaryati, Penelitian Hukum di Indonesia pada Akhir Abad ke-20,Bandung : Penerbit Alumni, cetakan ke-2, 2006.

D.A Tiasnaadmidjaja dalam Asep Warlan Yusuf. Pranata Pembangunan. Bandung: Universitas Parahiayang 1997.

HR ,Ridwan, Hukum Administrasi Negara,Ctk. Kesebelas,PT RAJA GRAFINDO PERSADA, Yogyakarta, 2014. Koeswahyono, Imam, Hukum Penatagunaan Tanah dan Penataan Ruang di Indonesia (ProblematikaAntara Teks dan Konteks),Ctk.

Pertama,UBPress,Malang,2012

Marbun, F, Hukum Administrasi Negara I (Administrative LawI), Ctk.Kedua,FH UII Press, Yogyakarta,2018.

Marbun,S.F, Hukum AdministrasiNegara I,Ctk. Pertama,FH UII Press, Yogyakarta, 2012.

Pudyatmoko, Y.Sri, Perizinan Problem dan upaya Pembenahan,

PT.Grasindo, 2009 Jakarta,

Siahaan , Pahala Marihot, (b), Hukum Bangunan Gedung di Indonesia, RajaGrafindo Persada, Jakarta, 2008.

Siahaan,Pahala Marihot, Pajak Daerah dan Retribusi Daerah. Raja Grafindo Persada : Jakarta, 2010.

Soekanto, Soerjono. Sosiologi Suatu Pengantar. Jakarta: Rajawali Pers, 2012.

Soekanto,Soerjono dan Sri Mamudji,Penelitian Hukum Normatif Suatu Tinjauan Singkat,Ctk 11 PT Raja Grafindo,Jakarta,2009

Sunarto, Pajak dan Retribusi

Daerah, Amus dan Citra Pustaka, Yogyakarta, 2005.
Sunarto dan Riduwan. Pengantar

Statistika Untuk

Penelitian:Pendidikan, Sosial, Komunikasi,

Ekonomi, dan Bisnis.

Bandung: Alfabeta.2013.

Sunggono, Bambang, Metodologi Penelitian Hukum, Jakarta: Rajawali Press, 1997.

Sunggono, Bambang, Metodologi Penelitian Hukum, Jakarta, PT Raja Grafindo Persada, 2012.

Sutedi, Andren, Hukum Perizinan Dalam Sektor Pelayanan

Publik, Ctk. Pertama, Sinar Grafika, Jakarta,2010.

Y.Sri Pudyatmoko, Perizinan Problem dan upaya Pembenahan, PT.Grasindo ,2009.

\section{Tesis - Tesis :}

Andi W.S, "Pelaksanaan Pelayanan Publik Dalam Pemberian Izin Mendirikan

Bangunan Di Kota Palopo", Program Studi Hukum AdministrasiNegara Fakultas Hukum Universitas Hasanuddin, 2017

Reza Dwi S, "Penegakan Hukum Bagi Bangunan Net City Yang Tidak Memiliki Izin Mendirikan

Bangunan (IMB) Di Kota Yogyakarta", Program Studi Ilmu Hukum Fakultas Hukum

Universitas Islam Indonesia Yogyakarta,2018

\section{Peraturan Perundang - undangan}

Undang-Undang Nomor 26 Tahun 2007 Tentang PenataanRuang (Lembaran Negara RepublikIndonesia Nomor 68 Tahun 2007, TambahanLembaran Negara Republik IndonesiaNomor 4725).

Undang-Undang Nomor 28 Tahun 2002 Tentang BangunanGedung 
Jurnal Pro Hukum: Vol . 10, No. 1, Juni 2021

LembaranNegara Republik

Indonesia Nomor 134 Tahun 2002, Tambahan LembaranNegara Republik Indonesia Nomor 4247).

Peraturan Pemerintah Nomor 36 Tahun 2005 TentangPeraturan Pelaksanaan Undang-Undang Nomor 28 Tahun 2002 Tentang Bangunan Gedung (Lembaran Negara Republik Indonesia Nomor 83 Tahun 2005, Tambahan Lembaran Negara Republik IndonesiaNomor 4532)

Peraturan Daerah Gresik Nomor 06 Tahun 2017

Tentang Izin MendirikanBangunan 